\title{
Serum and Intratesticular Sex Steroids in Azoospermic Men: How Do They Correlate?
}

\author{
J. HERÁČEK ${ }^{1}$, V. SOBOTKA ${ }^{1}$, L. KOLÁTOROVÁ ${ }^{2}$, J. KOČÁREK $^{1}$, R. HAMPL ${ }^{2}$ \\ ${ }^{1}$ Department of Urology, Military University Hospital Prague, Czech Republic, ${ }^{2}$ Institute of \\ Endocrinology, Prague, Czech Republic
}

Received August 6, 2018

Accepted August 21, 2018

\begin{abstract}
Summary
Five intratesticular sex steroids (testosterone, dihydrotestosterone, androstenedione, estradiol and epitestosterone) along with six serum hormones (LH, FSH, prolactin, SHBG, testosterone and estradiol) were determined in 84 non-obstructive azoospermic men, in order to evaluate to what extent serum and testicular tissue as well as individual hormones in the same material mutually correlate. With exception of androstenedione, tight correlations were found among tissue content of sex steroids, while only weak correlation was recorded between serum and testicular concentrations of major sex steroids testosterone and estradiol. It points to importance of measurement of intratesticular steroids in combination with examination of sperm parameters for assessment of testicular function and spermatogenesis.
\end{abstract}

\section{Key words}

Intratesticular tissue • Serum sex steroids • Azoospermia

\section{Corresponding author}

R. Hampl, Institute of Endocrinology, Národní 8, 11694 Prague, Czech Republic. E-mail: rhampl@endo.cz

\section{Introduction}

As many as $15 \%$ of couples do not achieve pregnancy within 1 year of unprotected sexual intercourse and turn to infertility clinics. Since male causes of infertility are found in about half of involuntarily childless couples, it can be assumed that approximately $7 \%$ of all men are confronted with fertility problems. In $50 \%$ a male infertility associated factor is found together with abnormal semen parameters (World Health
Organization 2000). Another factor represents endocrine disorders, as a potentially reversible cause of some cases of male-factor infertility. Therefore, a complete investigation of infertility should include endocrinological evaluation and semen and hormonal analysis. This is especially true where assisted reproductive techniques are becoming more advanced and more widely used (Sussman et al. 2008, Vitku et al. 2015, Vitku et al. 2018).

High levels of intratesticular testosterone secreted by the Leydig cells are necessary for spermatogenesis (Dohle et al. 2003, Lombardo et al. 2005). A number of studies have been published on intratesticular sex steroid concentrations in normal men as well as in men with various fertility disorders, including gonadotropin administration, for successful in vitro fertilization (Roth et al. 2010, Page 2011). From the point of view of endocrine/paracrine regulation, testes represent a microenvironment characterized by its own hormone metabolism and regulation mechanisms (Lin et al. 2007, Page 2011, Tremblay 2015). Therefore, circulating steroid hormones need not fully reflect the situation in the testis. In addition, it is well known that high levels of testosterone, needed inside the testis, cannot be achieved by oral or parenteral administration of androgens (Lin et al. 2007).

To what extent serum hormones in healthy men correlate with intratesticular ones has been addressed by Roth et al. (2010). Here we provide further data on five intratesticular sex steroids together with levels of six relevant hormones in serum and their mutual correlations in a group of azoospermic men. 


\section{Materials and Methods}

\section{Study group}

The testicular tissue was obtained from 84 nonobstructive azoospermic men aged 21-58 years (mean \pm SD: $35.7 \pm 9.7$ ) by surgical retrieval. Patients were evaluated by physical examination, comprehensive history, measurement of testicular volume, at least two semen analysis and hormonal parameters. All patients underwent screening for cystic fibrosis, Y chromosome microdeletion and karyotype analysis and showed normal results. Blood was removed from cubital vein and serum stored at $-70{ }^{\circ} \mathrm{C}$ until processed. Patients underwent microsurgical testicular sperm extraction (M-TESE) using optical x20-25 magnification (microscope OPMI Pico/S100, Carl Zeiss, Jena, Germany). M-TESE involves "bivalve" opening of the testicle by means of an equatorial or longitudinal incision under general or spinal anesthesia and removal of single tubules observed to have the largest diameter under an operating microscope and testicular pulp (Schlegel 1999). The material was immediately frozen in dry carbon dioxide and stored frozen at $-70{ }^{\circ} \mathrm{C}$ until processed.

A written informed consent was obtained from all patients and the study was approved by the Ethical Committee of the Institute of Endocrinology.

\section{Methods}

Serum hormones, LH, FSH, prolactin, testosterone and SHBG were measured by immunoassay using commercial kits from Immunotech (Czech division of Beckman Coulter, Marseille, France), estradiol by radioimmunoassay kit Spectria Estradiol RIA (Orion Diagnostica Oy, Espoo, Finland). Intratesticular hormones, testosterone, dihydrotestosterone, androstenedione, estradiol and epitestosterone were determined by a method originally used for measurement of sex steroids in prostatic tissue (Heracek et al. 2007). In brief, the procedure involved homogenization of the tissue, extraction with diethyl ether, solvent partition between n-hexane and aqueous methanol and high performance liquid chromatography for separation of the analytes, which were finally determined by specific radioimmunoassays (see above). The details of the method were described elsewhere (Zamrazilova et al. 2012).

\section{Statistical analysis}

Data were reported as mean \pm standard deviation
(SD), medians and upper and lower quartiles. The correlations among variables were analyzed using Spearman's correlation coefficients. A $p$ value $<0.05$ was considered to indicate significance. Statistical analysis was performed by the STATISTICA version 8 for Windows (Statsoft, Tulse, USA) software package.

\section{Results}

Serum gonadotropins, major sex steroids testosterone and estradiol and also prolactin and SHBG were determined in a group of 84 azoospermic men. Along with plasma hormones, intratesticular sex steroids were measured including dihydrotestosterone and testosterone precursor androstendione. In addition, epitestosterone was determined with respect to its role as potential antiandrogen (Starka 2003). The data on hormone concentrations are given in Table 1. Mutual correlations were further calculated between pairs of analyzed hormones in serum and intratesticular tissue, as summarized in Table 2.

\section{Discussion}

Investigation of sperm parameters along with measurement of basal or stimulated plasma sex hormones belong to classical tests for evaluation of male fertility. More recent studies point to importance of intratesticular steroids with respect to their role in spermatogenesis. Concerning the concentrations of intratesticular tissue testosterone, our results are very close to those reported by Roth et al. (2010) for healthy men $(2.2 \mathrm{nmol} / \mathrm{g}$ tissue compared to $2.2 \mathrm{nmol} / \mathrm{ml}$ ), but our data on dihydrotestosterone and estradiol are slightly higher, pointing to an excess of estrogens in azoospermia. In the latter study (Roth et al. 2010) intratesticular androgens correlated well with serum gonadotropin levels and also with serum testosterone, while in our study of azoospermic men only weak correlation was found between serum and tissue concentrations of testosterone $(\mathrm{r}=0.2622, \mathrm{p}=0.0196)$ and between serum and tissue concentrations of estradiol $(r=0.2306, p=0.0409)$. The serum levels of gonadotropins, prolactin and SHBG did not correlate with tissue concentrations of sex hormones at all.

On the other hand, there were very tight correlations among all intratesticular sex steroids, namely testosterone, dihydrotestoterone, estradiol and even epitestosterone (Table 2). The correlation of the latter 


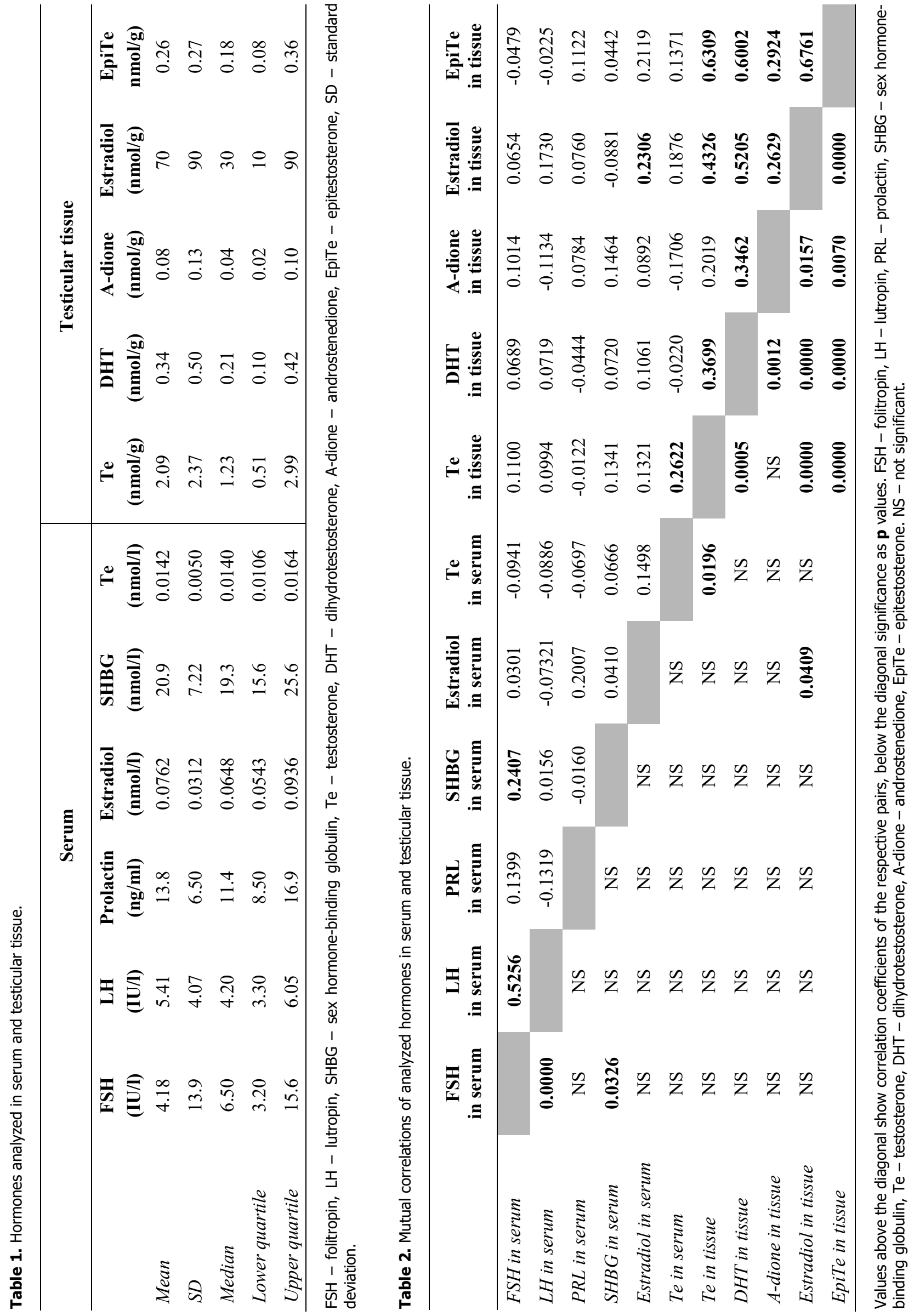


with all three sex hormones supports the idea of autonomous role of the testis in endocrine regulations and metabolism (Tremblay 2015). In conclusion, the results confirm the close relationship among intratesticular steroid hormones, which better reflect the situation in the testis than estimation of circulating hormones. Therefore, we suggest that measurement of intratesticular steroids, along with examination of sperm parameters may be a suitable tool for assessment of testicular function and spermatogenesis.

\section{Conflict of Interest}

There is no conflict of interest.

\section{Acknowledgements}

The study was supported by a project of the Ministry of Health of the Czech Republic - RVA (,Endokrinologický ústav - EÚ00023761“).

\section{References}

DOHLE GR, SMIT M, WEBER RF: Androgens and male fertility. World J Urol 21: 341-345, 2003.

HERACEK J, HAMPL R, HILL M, STARKA L, SACHOVA J, KUNCOVA J, EIS V, URBAN M, MANDYS V: Tissue and serum levels of principal androgens in benign prostatic hyperplasia and prostate cancer. Steroids 72: 375-380, 2007.

LIN YM, POON SL, CHOI JH, LIN JS, LEUNG PC, HUANG BM: Transcripts of testicular gonadotropin-releasing hormone, steroidogenic enzymes, and intratesticular testosterone levels in infertile men. Fertil Steril 90: 1761-1768, 2008.

LOMBARDO F, SGRÒ P, SALACONE P, GILIO B, GANDINI L, DONDERO F, JANNINI EA, LENZI A: Androgens and fertility. $J$ Endocrinol Invest 28: 51-55, 2005.

PAGE ST: Physiologic role and regulation of intratesticular sex steroids. Curr Opin Endocrinol Diabetes Obes 18 : 217-223, 2011.

ROTH MY, LIN K, AMORY JK, MATSUMOTO AM, ANAWALT BD, SNYDER CN, KALHORN TF, BREMNER WJ, PAGE ST: Serum LH correlates highly with intratesticular steroid levels in normal men. J Androl 31: 138-145, 2010.

SCHLEGEL PN: Testicular sperm extraction: microdissection improves sperm yield with minimal tissue excision. Hum Reprod 14: 131-135, 1999.

STARKA L: Epitestosterone. J Steroid Biochem Mol Biol 87: 27-34, 2003.

SUSSMAN EM, CHUDNOVSKY A, NIEDERBERGER CS: Hormonal evaluation of the infertile male: Has it evolved? Urol Clin North Am 35: 147-155, 2008.

TREMBLAY JJ: Molecular regulation of steroidogenesis in endocrine Leydig cells. Steroids 103: 3-10, 2015.

VITKU J, SOSVOROVA L, CHLUPACOVA T, HAMPL R, HILL M, SOBOTKA V, HERACEK J, BICIKOVA M, STARKA L: Differences in bisphenol A and estrogen levels in the plasma and seminal plasma of men with different degrees of infertility. Physiol Res 64 (Suppl 2): S303-S311, 2015.

VITKU J, KOLATOROVA J, RICCO C, FERROUD C, HENNEBERT O, SKODOVA T, HERACEK J, STARKA L: The quantitation of 7 $\beta$-hydroxy-epiandrosterone in the plasma and seminal plasma of men with different degrees of fertility. Physiol Res 67 (Suppl 3): S511-S519, 2018.

WORLD HEALTH ORGANIZATION: WHO Manual for the Standardised Investigation and Diagnosis of the Infertile Couple. Cambridge University Press, Cambridge, 2000, p. 19.

ZAMRAZILOVA L, SOSVOROVA L, HERACEK J, SOBOTKA V, HAMPL R: The content of five sex steroids in human testis. Physiol Res 61: 221-225, 2012. 